\title{
Genetic divergence and phylogenetic relationships among Salmo trutta L. (brown trout) populations from Greece and other European countries
}

\author{
A. APOSTOLIDIS*, Y. KARAKOUSIS \& C. TRIANTAPHYLLIDIS \\ Department of Genetics, Development and Molecular Biology, School of Biology, Aristotle University of \\ Thessaloniki, 54006 Thessaloniki, Macedonia, Greece
}

\begin{abstract}
In order to clarify the genetic structure and the phylogenetic relationships among brown trout (Salmo trutta) populations from Greece and other European countries starch gel electrophoresis was used. The populations come from various rivers from Greece and other European countries, flowing to the Atlantic or to the Mediterranean. Eleven enzymic systems were investigated. These correspond to 26 putative loci. A high degree of genetic polymorphism was found. The percentage of polymorphic loci ranged from 3.8 to 34.6 and the degree of expected heterozygosity from 0.016 to 0.1 . $F$-statistics and clustering analyses indicated the existence of a high degree of differentiation. This differentiation is mainly between the Atlantic and the Mediterranean populations. Furthermore the Mediterranean populations seem to be divided into two groups. One includes the western Mediterranean populations and populations from western Greece and the other north-eastern Greek populations. The latter seem to be related to other Balkan populations and probably to Danubian or Black Sea populations. These results support the idea of two different lineages of Mediterranean brown trout populations, one of which is probably of aboriginal origin.
\end{abstract}

Keywords: allozyme, brown trout, genetic polymorphism, Greece, phylogeny, Salmo trutta.

\section{Introduction}

The brown trout (Salmo trutta L.) is one of the best studied native salmonids of Europe. Its natural distribution includes diverse areas from North Africa and the Mediterranean regions to tributaries of the Caspian and Aral Seas and to Scandinavia. Furthermore, the species exhibits a high degree of variability in characters such as life history and morphology. As a result a great number of previously described forms are now considered to belong to the Salmo trutta species (MacCrimmon \& Marshall, 1968; Elliott, 1989).

The first studies on the genetic structure of this species, using allozymic data, were performed on Atlantic populations (Allendorf et al., 1976; Ryman et al., 1979; Ferguson \& Mason, 1981; Crozier \& Ferguson, 1986; Hansen et al., 1993). These studies revealed, in some cases, a complex genetic structure

\footnotetext{
${ }^{*}$ Correspondence.
}

which can be related either to ecological parameters (e.g. adaptation to different environmental regimes) or to historical reasons (e.g. influence of glacial extensions) or to both (Ferguson, 1989; Hamilton et al., 1989). Generally, it seems that the Atlantic populations did not exhibit a high degree of genetic diversity. This could be the result of the last glacial extension, when most of northern Europe was covered with glaciers and the contemporary populations of brown trout, in this region, had their origin from a few refugia.

Population genetics studies on brown trout from Mediterranean drainages indicate that these populations are genetically distinct from Atlantic populations (Krieg \& Guyomard, 1985; Guyomard, 1989; Garcia-Marin et al., 1991). Another important feature of the Mediterranean populations, revealed by these studies, was their high degree of genetic diversity (Guyomard \& Krieg, 1983; Krieg \& Guyomard, 1983; Karakousis \& Triantaphyllidis, 1990). Similar results have been reported for brown trout 
populations of the Black and Caspian Seas. These populations seem to differ significantly from populations of the Baltic and White Sea drainages and to exhibit a high degree of differentiation among themselves, as a result of bottleneck phenomena (Osinov, 1984, 1989, 1990).

The origin of the Mediterranean brown trout populations is a matter of debate. Several authors consider the brown trout populations of the Mediterranean, Black and Caspian Seas as a component of the northern ichthyofauna, which invaded southern drainages through glacial flows (during the glacial periods) (Osinov, 1989). Alternatively, the brown trout populations of these regions could be ancient aboriginal forms which have existed since the Pliocene. Nevertheless, according to Balon (1968) the brown trout populations of the Mediterranean drainages have their origin in ancestral anadromous populations of Salmo trutta mediterranea which disappeared from the sea during the last interglacial period (300 $000 \mathrm{BP})$. It is more probable that a combination of all these events has had an impact on the genetic diversity found in these populations. Therefore it seems that there is more than one lineage in the Mediterranean region and some are of ancient origin.

In order to clarify the origin and diversification of Mediterranean brown trout populations we used allozyme analysis. Other methods, such as mtDNA analysis, are also currently being used in our laboratory. Recent studies using microsatellite analysis support the distinctiveness of Mediterranean populations from Atlantic ones (Estoup et al., 1993; Presa et al., 1994). Studies on mtDNA sequence variation of control-region and protein-coding genes support the existence of different lineages in the Mediterranean drainages (Bernatchez et al., 1992; Giuffra et al., 1994).

The aim of the present investigation is to examine the population genetic structure of brown trout populations of Greece and to clarify their phylogenetic relationships with other European populations. Previous results from our laboratory indicated the existence of a rather high degree of differentiation among the north and north-western Greek populations (Karakousis \& Triantaphyllidis, 1988, 1990). In this study we included populations of brown trout from the western and southern regions of the country. The freshwater fish fauna of these regions belongs to a different ichthyogeographical zone (Economidis \& Banarescu, 1991). The identification of different lineages in populations in such a restricted area as Greece is important for proper management policy designed to protect this species.

\section{Materials and methods}

Samples of brown trout were collected, by electrofishing, from eight different streams from western and south-western Greece (Fig. 1). Furthermore, samples from different European regions were included in the analysis. These are: one sample of $S$. trutta letnica from Lake Ohrid (Albania); one sample from the Tachov, a tributary of the Elbe in the Czech Republic; two samples from France, one from the river Caranca (Mediterranean drainage) and the other from the river Garonne, Pyrenees (Atlantic drainage); two samples from Spain, one from the river system of Jucar (Mediterranean drainage) and the other from a hatchery population with unknown origin (Fig. 1). Sample sizes are indicated in Table 1.

Samples of tissues (white muscle, liver, heart, eye) were brought to the laboratory in liquid nitrogen, or on dry ice and in some cases on wet ice. Starch gel electrophoresis was used. Eleven enzymic systems were investigated (aspartate aminotransferase (AAT, EC 2.6.1.10), $\alpha$-glycerophosphate dehydrogenase $(\alpha-\mathrm{GPDH}, \mathrm{EC}$ 1.1.1.8), creatine kinase (CK, EC 2.7.3.2), isocitrate dehydrogenase (IDH, EC 1.1.1.42), lactate dehydrogenase (LDH, EC 1.1.1.27), malate dehydrogenase (MDH, EC 1.1.1.37), malic enzyme (ME, EC 1.1.1.40), phosphoglucose isomerase (PGI, EC 5.3.1.9), phosphoglucomutase (PGM, EC 5.4.2.2), 6-phosphogluconate dehydrogenase (6-PGDH, EC 1.1.1.43) and superoxide dismutase (SOD, EC 1.15.1.1)). These enzymes correspond to 26 putative loci. Tissues, buffers and electrophoretic conditions examined in each enzymic system were according to Karakousis \& Triantaphyllidis (1990).

Global indices such as allele frequencies, tests for Hardy-Weinberg equilibrium, Nei's (1978) genetic distance and identity and UPGMA cluster analysis were performed using the BIOSYS-1 computer program (Swofford \& Selander, 1981). In the final analysis ( $F$-statistics and clustering) we included data from previous investigations from our laboratory (Karakousis \& Triantaphyllidis, 1988, 1990). The $F$ statistics were performed according to Weir \& Cockerham's (1984) procedure and the differences of $F_{\text {ST }}$ values among populations for each locus were tested with the $\chi^{2}$-test, $\chi^{2}=2 N F_{\mathrm{ST}}(k-1)$ with $(k-1)(s-1)$ degrees of freedom, where $N$ is the total sample size, $k$ is the number of alleles for the locus and $s$ is the number of subpopulations (Chesser, 1983). The deviation of $F_{\text {IS }}$ from zero was tested by $\chi^{2}=N F_{\text {IS }}^{2}$, where $N$ is the total sample size (Hedrick, 1985).

The differentiation of the populations was further analysed using the correspondence analysis of the NTSYS program (Rohlf, 1990).

(C) The Genetical Society of Great Britain, Heredity, 76, 551-560. 


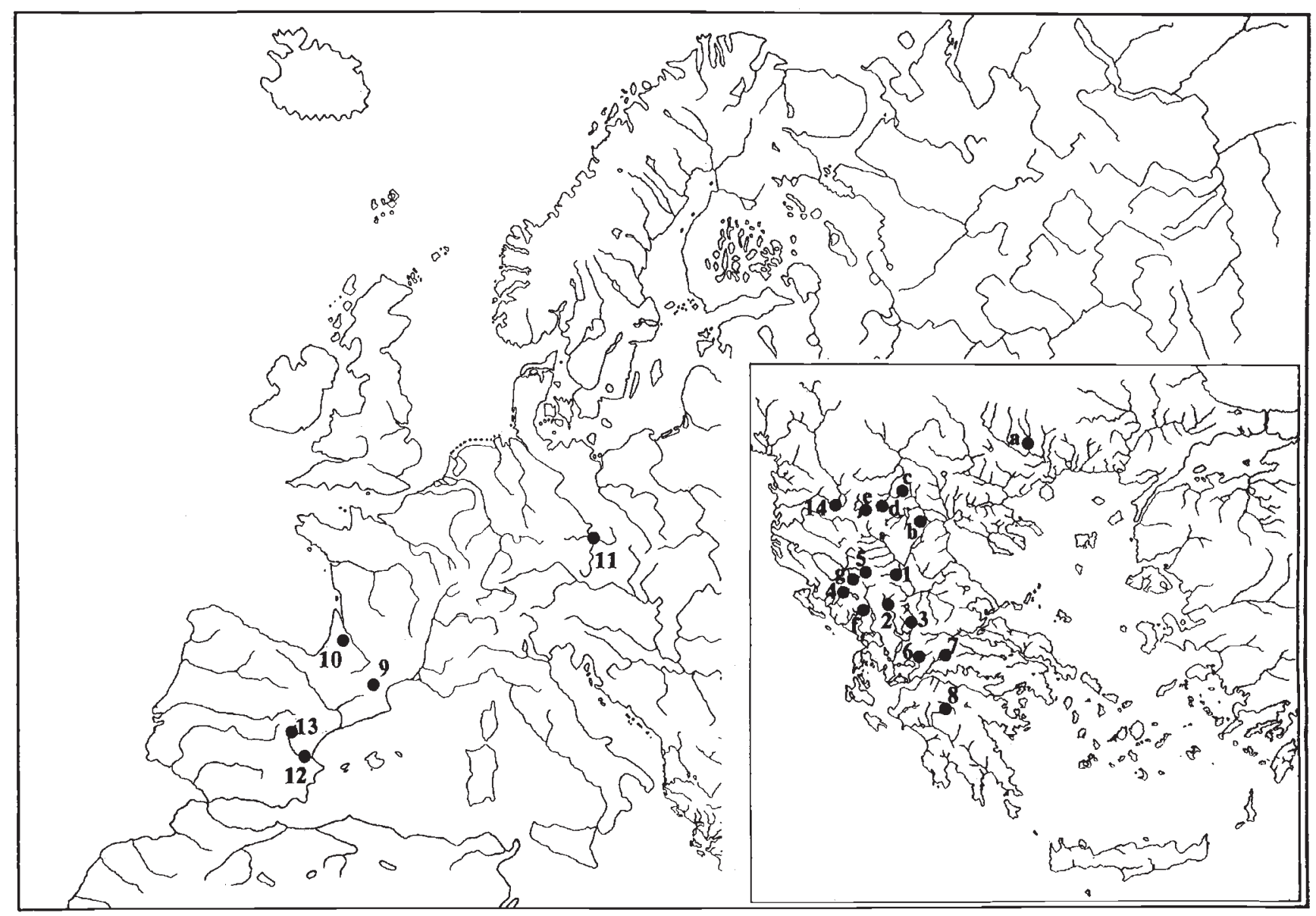

Fig. 1 Sampling sites: 1, Venetikos; 2, Acheloos 1; 3, Acheloos 2; 4, Thyamis; 5, Aoos; 6, Evinos; 7, Mornos; 8, Alfios; 9, Caranca; 10, Garonne; 11, Tachov; 12, Jucar 1; 13, Jucar 2; 14, Ohrid. The letters indicate sampling collections from previous investigations (Karakousis and Triantaphyllidis, 1990): a, Nestos; b, Tripotamos; c, Skopos; d, Drosopigi; e, Agios Germanos; f, Louros; g, Voidomatis.

Table 1 Sample size, mean number of alleles per locus (M.n.a.), percentage of polymorphic loci $(P)$, observed heterozygosity $\left(H_{\mathrm{o}}\right)$ and expected heterozygosity $\left(H_{\mathrm{e}}\right)$ of the 14 populations of Salmo trutta investigated

\begin{tabular}{lccrcc}
\hline Population & Sample size & M.n.a. & $P$ & $H_{\mathrm{o}}$ & $H_{\mathrm{e}}$ \\
\hline 1. Venetikos (G) & 37 & 1.2 & 15.4 & 0.029 & 0.037 \\
2. Acheloos 1(G) & 40 & 1.1 & 7.7 & 0.023 & 0.024 \\
3. Acheloos 2 (G) & 47 & 1.1 & 11.5 & 0.047 & 0.038 \\
4. Thyamis (G) & 43 & 1.1 & 3.8 & 0.018 & 0.019 \\
5. Aoos (G) & 45 & 1.2 & 11.5 & 0.035 & 0.031 \\
6. Evinos (G) & 35 & 1.1 & 11.5 & 0.020 & 0.029 \\
7. Mornos (G) & 37 & 1.2 & 15.4 & 0.039 & 0.035 \\
8. Alfios (G) & 10 & 1.2 & 15.4 & 0.046 & 0.053 \\
9. Caranca (F) & 30 & 1.0 & 3.8 & 0.017 & 0.016 \\
10. Garonne (F) & 30 & 1.2 & 23.1 & 0.098 & 0.093 \\
11. Tachov (CZ) & 20 & 1.3 & 26.9 & 0.100 & 0.100 \\
12. Jucar 1 (E) & 20 & 1.4 & 34.6 & 0.077 & 0.098 \\
13. Jucar 2 (E) & 23 & 1.3 & 11.5 & 0.027 & 0.028 \\
14. Ohrid (A) & 40 & 1.1 & 11.5 & 0.037 & 0.039 \\
\hline
\end{tabular}

Letters in parentheses indicate country of origin: G, Greece; F, France; CZ, Czech Republic; E, Spain; A, Albania. 


\section{Results}

Eleven out of 26 loci were monomorphic in all populations examined (Table 2). Forty-three alleles were found, but all these alleles, with the exception of one, have been reported by other investigators in previous studies. The new allele $(I D H-4 * 47)$ was found in the population of Evinos in only one individual (Table 2). Most of the polymorphic loci in the populations examined were in good agreement with Hardy-Weinberg expectations. Only five out of 53 tests were found to show significant statistical deviations after Bonferoni correction (Rice, 1989) (Table 2).

The mean number of alleles per locus ranged from 1.0 to 1.4 . The percentage of polymorphic loci $(P)$ ranged from 3.8 to 34.6 (a locus is considered polymorphic if more than one allele is detected). The values of observed heterozygosity $\left(H_{\mathrm{o}}\right)$ ranged from 0.017 to 0.1 and of the expected heterozygosity $\left(H_{\mathrm{e}}\right)$ from 0.016 to 0.1 (Table 1). The values for genetic distance ranged from 0.0 to 0.212 (Table 3 ).

The genetic diversity of the populations examined was further investigated using $F$-statistics (Weir \& Cockerham, 1984) (Table 4). $F_{\text {IS }}$ values provide estimations of Hardy-Weinberg equilibrium; deviations from 0 indicate deviations from Hardy-Weinberg expectation. The mean value found $(0.0423)$ indicates that most of the loci are in good agreement with expectation. There is no significant deviation from $0\left(\chi^{2}=1.33 ; P>0.05\right) . F_{\mathrm{ST}}$ values provide estimates of differentiation among populations and were found to be significant for all loci (Table 4), indicating a great degree of genetic diversity.

Based on these values and on data from previous investigations (Karakousis \& Triantaphyllidis, 1990) a UPGMA dendrogram was constructed (Fig. 2). The tree indicates the existence of three groups of populations, with the exception of the Agios Germanos population which clustered as a separate group. The first group (i) includes populations from northern Greece, the Ohrid trout and the population of brown trout from the Peloponnese (Alfios). The second group (ii) consists of populations from western Greece and Mediterranean drainages from France and Spain. The third group (iii) consists of populations from the Atlantic drainages (Fig. 2).

The genetic relationships among populations were further investigated using correspondence analysis. Axis 1 of the analysis with an explanatory power of 33.16 per cent mainly differentiates the Atlantic populations (populations numbers: 10, 11, 12) (Fig. 3 ). Axis 2 explains 18.63 per cent of the variance and accentuates the differentiation of the Agios Germa- nos population (Fig. 3). In the same figure, the alleles which contribute mainly to the differentiation of the populations are also indicated. The results of this analysis demonstrate the divergence of the Atlantic and Mediterranean populations.

\section{Discussion}

\section{Genetic polymorphism}

Forty-three alleles were found in the present investigation (Table 2). As indicated from the results of correspondence analysis (Fig. 3), it is interesting to note the geographical distribution of some of these alleles. $\quad C K-1 * 115, \quad I D H-3 * 160, \quad L D H-5 * 90$, $P G I-3 * 110,6-P G D H-1 * 86$ exist only in the Atlantic drainage systems. These alleles were reported from other investigators as 'Atlantic' alleles (Ferguson, 1989; Hansen et al., 1993). The $L D H-5 * 90$ is considered as a new allele of brown trout, which does not exist in other salmonid species, and its distribution among Atlantic populations seems to be related to glacial extension (Hamilton et al., 1989). The allele was not found in the Mediterranean populations examined. On the other hand, other alleles exist only in the Mediterranean populations, such as $L D H-2 * n$ and $M E-2 * 50$. The latter allele was found only in the Greek populations and its frequency was high in western Greek populations. Osinov (1989) reported a polymorphism with two alleles, '100' and ' 90 ', in the populations of the Caspian Sea drainages. A similar polymorphism to the $M E-2 *$ locus, with two alleles, '100' and ' 125 ', has been reported in the Atlantic Salmon, Salmo salar (Cross et al., 1978). This polymorphism was found to be clinal with latitude and highly correlated with summer temperature, with the '100' allele predominating in southern populations (Verspoor \& Jordan, 1989). In the absence of direct comparisons, it is difficult to speculate about the similarity between the brown trout and Atlantic salmon $\mathrm{Me}-2 *$ alleles and the ' 50 ' and ' 90 ' alleles of brown trout. The allele $M E-2 * 50$ was not found in the western Mediterranean drainage systems, indicating that this could be either a new allele appearing in the region of the eastern Mediterranean (southern Balkans and Asia Minor) and probably in the Caspian drainages too, or perhaps an ancestral one similar to the ' 100 ' allele of the Atlantic salmon which remains in those regions.

Null alleles were found at the $L D H-1^{*}$ and $L D H-2 *$ loci. A null allele at the $L D H-1 *$ locus has been described at high frequency in populations of brown trout in Swedish lakes (Allendorf et al., 1984). The effects on fitness of this null allele would vary 


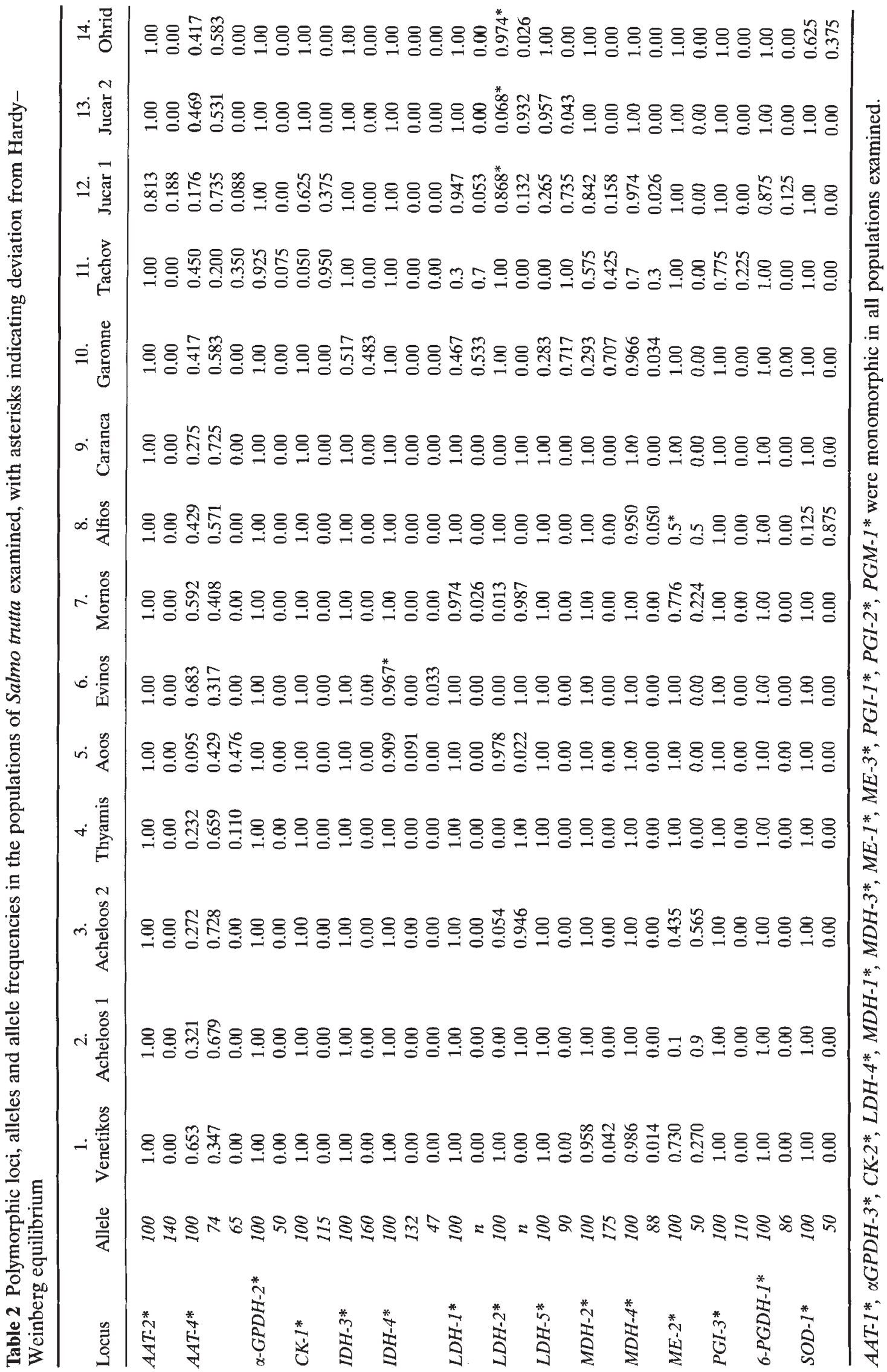

(c) The Genetical Society of Great Britain, Heredity, 76, 551-560. 
Table 3 Genetic identity (above diagonal) and genetic distance (below diagonal) of the Salmo trutta populations examined and seven populations previously investigated

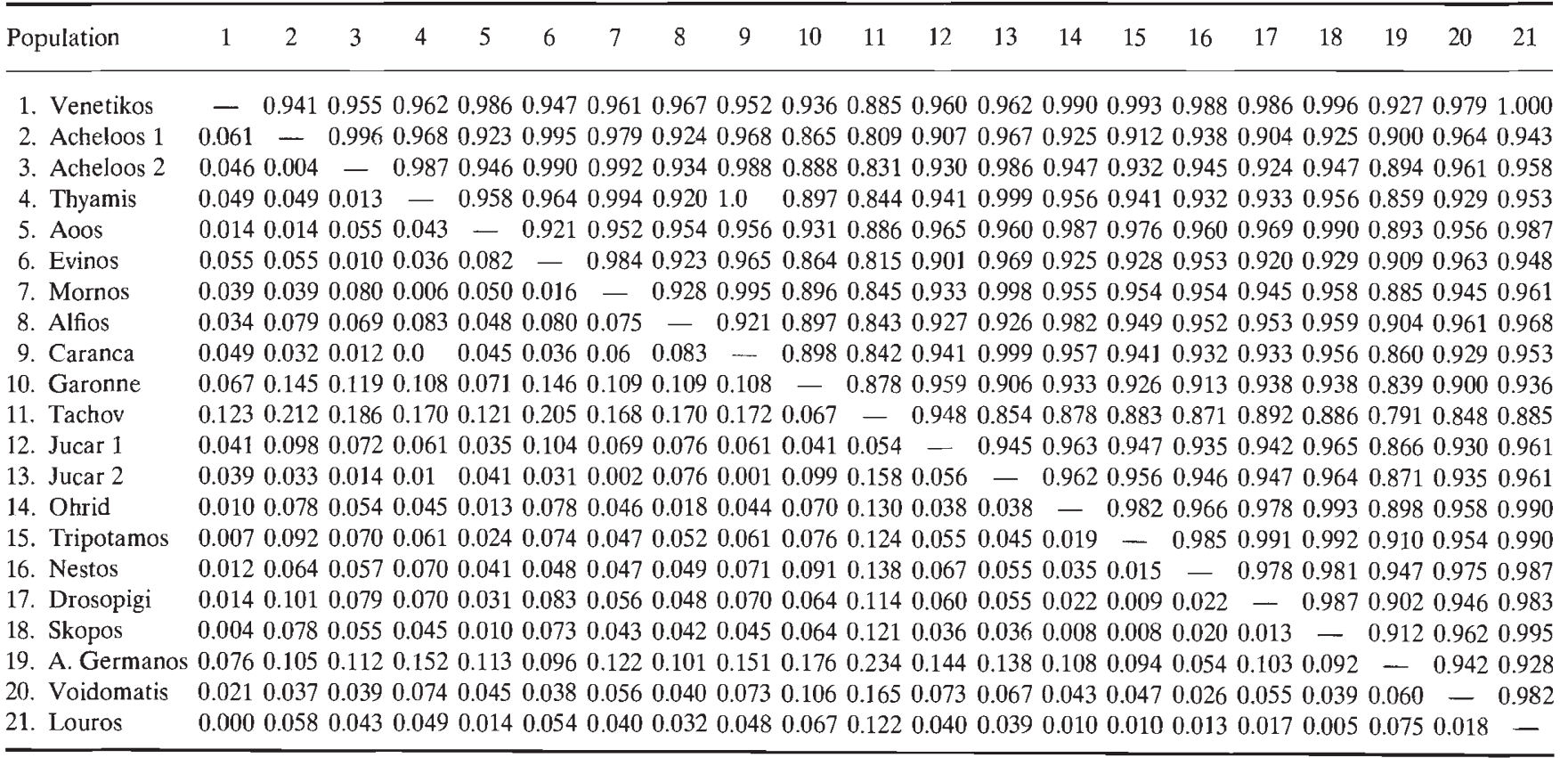

with environmental conditions, thus reduced amounts of LDH activity may have little metabolic effect on trout living in a lake. Nevertheless, $L D H-1^{*} n$ was found not only in lacustrine populations but in riverine ones also (Ferguson, 1989; Hansen et al., 1993) (Table 2). It seems probable that at least in brown trout there is not a direct relation between the presence of the null allele and environmental conditions. Leary et al. (1993) reported a high frequency of a null allele at the LDH- * $^{*}$ locus in rainbow trout (Oncorhynchus mykiss) and they suggested that the high frequency is the result of near selective neutrality of these genotypes in certain environments.

A polymorphism was found at the $\mathrm{LDH}-2 *$ locus, which can also be attributed to a null allele. This allele was at high frequency or even fixed in some populations (Table 2). Generally, null alleles are rare in populations of diploids because of harmful phenotypic effects in homozygotes. Nevertheless, the loss of duplicate gene expression in polyploid fishes, such as salmonids, has been a common occurrence resulting in the existence of null alleles (Allendorf $e t$ al., 1975; Li, 1980). According to $\mathrm{Li}(1980)$ duplicate genes, such as $L D H-1^{*}$ and $L D H-2^{*}$, which do not exhibit tissue specificity or ontogenetic regulatory divergence provide the greatest opportunity for fixation of a null allele at one locus. This assumes that a null allele at only one locus will not be selec- ted against. Probably this is the situation for the $L D H-2 * n$ allele in the populations examined, where in some instances this allele was fixed (Table 2).

Nei (1975) regards mean heterozygosity as the most important way of measuring genetic variation. Ferguson (1989) reported that the values of observed heterozygosity range between 0 and 0.122 for brown trout populations. The degree of heterozygosity found in the present investigation varied significantly among the populations examined, but it is within the values reported for other populations of this species, with the 'Atlantic' populations exhibiting the higher values (Table 1). The low degree of heterozygosity in some cases could be the result of bottleneck events. Most of the populations examined from the Mediterranean drainages live in small streams where fluctuations in the population size are probable; this results in a reduction of the genetic variability. Low values of genetic variability have been reported for populations of brown trout from the Aral Sea basin (Osinov, 1990).

The values for genetic distance found in the populations examined ranged from 0 to 0.212 (Table 3 ). The highest values were found among the Mediterranean and the Atlantic populations. Ferguson (1989) reported an average value for Nei's (1972) coefficient of mean genetic distance among brown trout populations of 0.026 . This is typical of conspecific populations. Nevertheless, Osinov (1984) found 
Table 4 Results of $F$-statistics analysis for the studied populations of Salmo trutta

\begin{tabular}{lccccr}
\hline Locus & \multicolumn{1}{c}{$F_{\text {IS }}$} & $F_{\text {IT }}$ & $F_{\text {ST }}$ & $\chi^{2}$ & d.f. \\
\hline$A A T-2^{*}$ & -0.1005 & 0.2740 & 0.3403 & $965.09^{*}$ & 40 \\
$A A T-4^{*}$ & -0.0527 & 0.2504 & 0.2879 & $813.02^{*}$ & 40 \\
$\alpha-G P D H-2^{*}$ & 0.2733 & 0.4215 & 0.2040 & $343.12^{*}$ & 20 \\
$C K-1^{*}$ & 0.3043 & 0.9112 & 0.8724 & $1378.39^{*}$ & 20 \\
$C K-2^{*}$ & 1.00 & 1.00 & 1.00 & $1580.0^{*}$ & 20 \\
$I D H-3^{*}$ & 0.4128 & 0.6907 & 0.4733 & $627.59^{*}$ & 20 \\
$I D H-4^{*}$ & 0.1830 & 0.2818 & 0.1209 & $322.56^{*}$ & 40 \\
$L D H-1^{*}$ & 0.0849 & 0.4227 & 0.3692 & $630.59^{*}$ & 20 \\
$L D H-2^{*}$ & 0.2685 & 0.9304 & 0.9048 & $1545.39^{*}$ & 20 \\
$L D H-5^{*}$ & 0.1985 & 0.8182 & 0.7732 & $1167.53^{*}$ & 20 \\
$M D H-2^{*}$ & -0.0637 & 0.4224 & 0.4569 & $662.5^{*}$ & 20 \\
$M D H-4^{*}$ & -0.2820 & -0.0143 & 0.2088 & $302.76^{*}$ & 20 \\
$M E-2^{*}$ & 0.1926 & 0.6854 & 0.6103 & $1042.39^{*}$ & 20 \\
$P G I-3^{*}$ & 0.0125 & 0.2262 & 0.2164 & $286.94^{*}$ & 20 \\
6-PGDH-1* & -0.1274 & 0.0039 & 0.1165 & $158.20^{*}$ & 20 \\
$S O D-1^{*}$ & 0.1519 & 0.5315 & 0.4476 & $607.84^{*}$ & 20 \\
Mean & 0.0423 & 0.5808 & 0.5623 & $12433.91^{*}$ & 340 \\
\hline
\end{tabular}

*Significant at $P<0.001$.

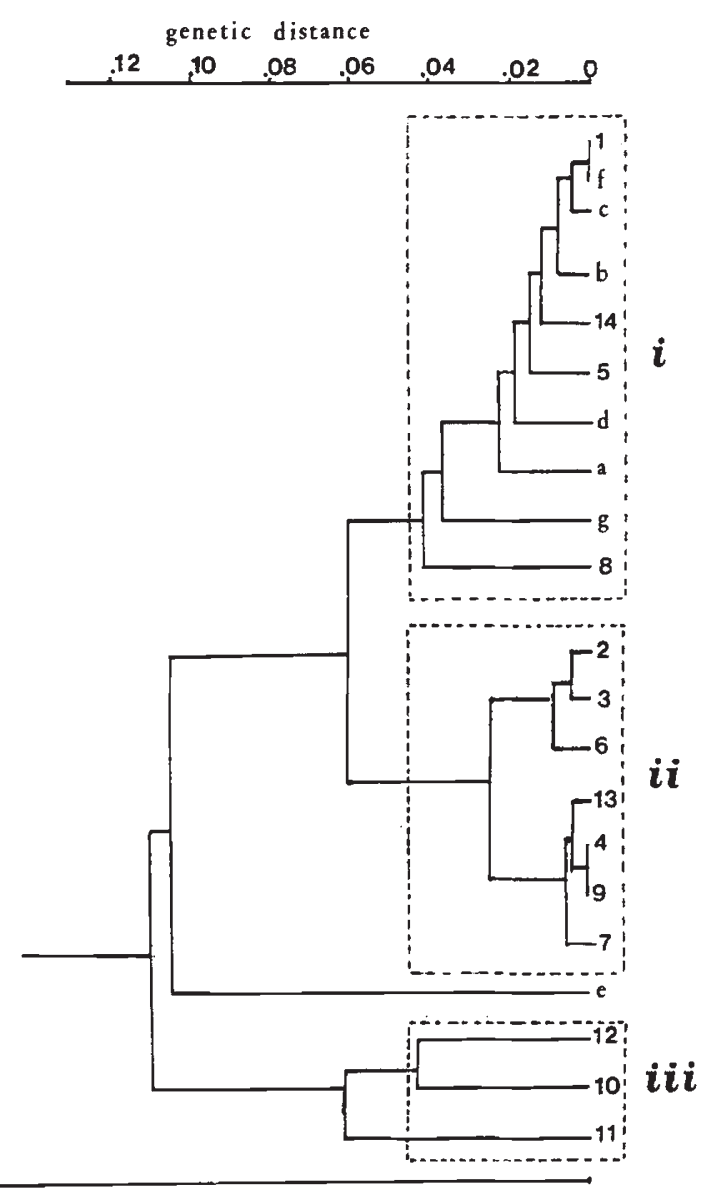

(C) The Genetical Society of Great Britain, Heredity, 76, 551-560. a value for genetic distance of 0.07 among White Sea and Black Sea populations. Guyomard (1989) also reported a degree of genetic distance of 0.1 to 0.15 among Mediterranean and Atlantic populations of France. The values found in the present investigation indicate the great genetic divergence among the Atlantic and Mediterranean brown trout populations, which can reach specific level if we take into account that the equivalent values for brown trout and Atlantic salmon are 0.33 (Ferguson \& Fleming, 1983). This is more apparent if we consider the results of $F$-statistics (Table 4 ) where the value of $F_{\mathrm{ST}}$ is 0.5623 . Similar results have been reported for French populations (Krieg \& Guyomard, 1985). These results indicate that the biggest proportion of variability is distributed among populations, a result which is important from a management perspective.

\section{Origin of populations in relation to palaeogeographical events}

The UPGMA tree (Fig. 2) suggests that there are four clusters, one of which consists only of the population from Agios Germanos (population e). The Ohrid trout has been classified as a different subspecies

Fig. 2 UPGMA dendrogram based on Nei's (1978) genetic distance values for the populations of Salmo trutta examined in the present investigation and for previous data. 


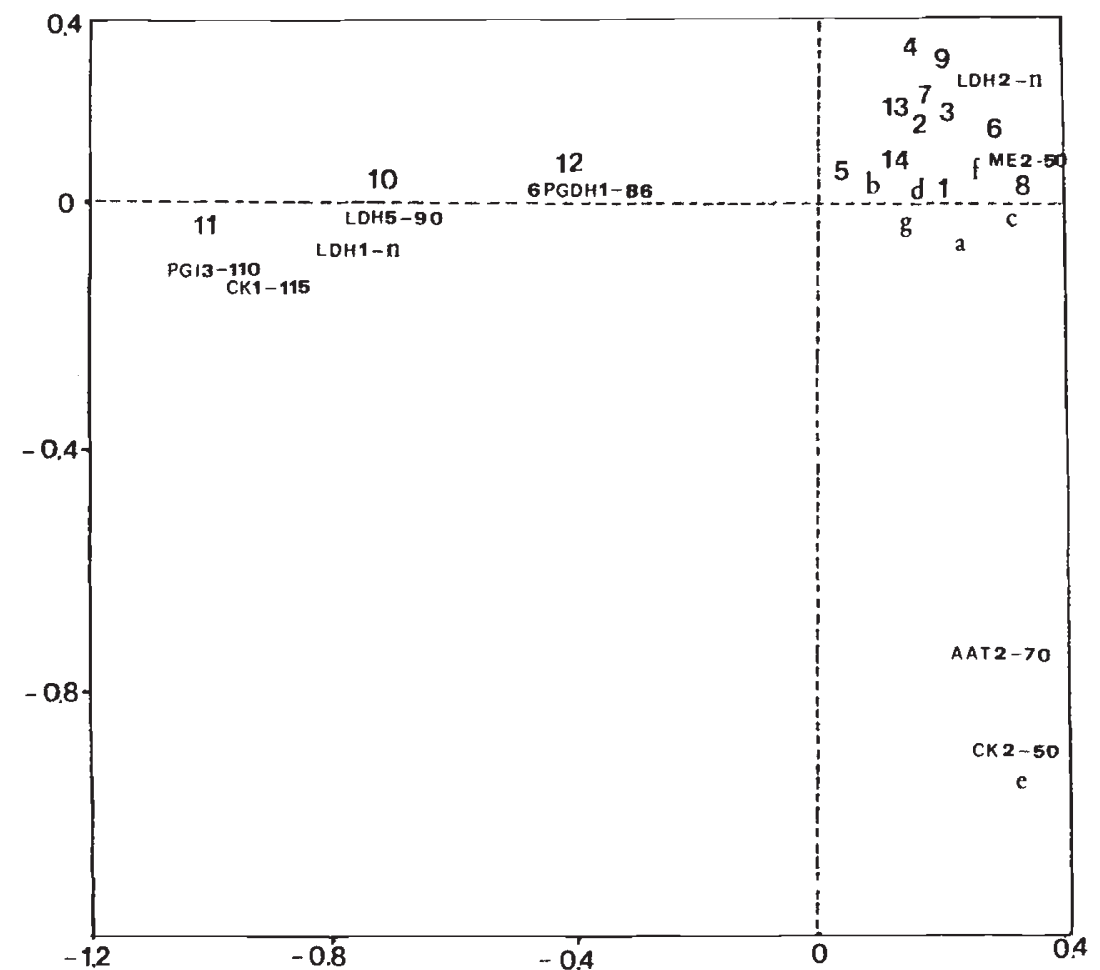

Fig. 3 Simultaneous representation of Salmo trutta populations and alleles on the two axes of correspondence analysis. based on morphological and life history traits. The results of the allozymic analysis do not support such a classification. It is interesting to note that the Ohrid and the Prespa lakes have the same geological origin and probably the trout populations in both lakes also have the same origin; nevertheless it seems that great genetic divergence exists between the two populations. The population of Agios Germanos (drainage of Prespa) seems to diverge significantly from the rest of the Mediterranean populations. Its divergence could be either the result of genetic drift, owing to isolation of the population in a small stream flowing to the Prespa lake or represents an ancient aboriginal stock of this species. It would be interesting to know the genetic structure of other brown trout populations from the same region in the former Yugoslavia.

The results of the present investigation indicate clearly the existence of two different lineages in Greek brown trout populations. The clustering of the populations into the two different lineages corresponds to the delimitation of two different ichthyogeographical zones in Greece: the south Adriatic-Ionian zone, which includes rivers of western and south-western Greece; and the PontoAegean zone, which includes rivers of northern and north-eastern Greece. The freshwater fishes of the latter zone are closely connected with the ichthyofauna of the Danubian and Black Sea rivers (Bianco,
1990; Economidis \& Banarescu, 1991). It seems more probable that the brown trout populations of this region are related to Danubian and Black Sea stocks. In contrast, the populations of western Greece seem to be related to western Mediterranean stocks. The only exception is the population from the Alfios river, in the Peloponnese, a river which belongs to Adriatic-Ionian zone, and its brown trout population seems to be related to north-eastern populations of the species.

The divergence of the populations seems to be related to geological events. If the hypothesis of a molecular clock is valid, the time of divergence of different populations of a species or of different species can be approximately calculated from the values of Nei's genetic distance. Nevertheless, there is disagreement between various investigators about the value of the constant $k$ in Nei's equation $(t=k D$, where $t=$ time of divergence and $D=$ genetic distance); sometimes this disagreement reaches a 4 -fold difference. For fishes it is proposed that the value of the constant $k$ is $20 \times 10^{6}$ (Vawter et al., 1980). Therefore the time of divergence between the Atlantic and Mediterranean populations is about 4 million years (late Miocene-Pliocene). The main geological event at this time was the isolation of the Mediterranean from the Atlantic and its transformation into a lake (Lago Mare) with connections to the Paratethys Sea (Black Sea and Caspian Sea) (Stei- 
nenger \& Rogl, 1984). The isolation of the Mediterranean from the Atlantic populations seems to date from that time. The time of separation of the Mediterranean stocks is about 1.6 million years (Pleistocene). This is related to the beginning of the glacial periods, where isolation of the Aegean Sea from the rest of the Mediterranean and close connection of the North Aegean rivers with the Black Sea and Danubian drainages have been recorded (Bianco, 1990). Perhaps the western lineage represents the Mediterranean $S$. $t$. macrostigma subspecies and the other lineage is related to Black Sea and Danubian trouts. These results do not support the idea of a Northern (Atlantic) origin of the Mediterranean brown trout populations. It is more probable that these populations represent ancient aboriginal forms of this species. The phylogentic relationships of these populations are under investigation at the mitochondrial DNA level as well.

\section{Acknowledgements}

The authors are indebted to Dr P. Berrebi, Dr I. Doadrio, Dr F. Gutierrez and Dr V. Slechta for providing samples; to Prof. P. Economidis and Dr A. Kouvatsi for their fruitful discussions and to $\mathrm{Mr} \mathbf{R}$. Clarembaux for his valuable help in correcting the manuscript. Financial support from the European Commission within the framework EV5VCT920097 project is gratefully acknowledged.

\section{References}

ALLENDORF, F. W., UTTER, F. M. AND MAY, B. P. 1975. Gene duplication within the family Salmonidae: II. Detection and determination of the genetic control of duplicate loci through inheritance studies and the examination of populations. In: Markert, C. L. (ed.) Isozymes IV: Genetics and Evolution, pp. 415-532. Academic Press, New York.

ALLENDORF, F. W., RYMAN, N., STENNEK, A. AND STÅHL, G. 1976. Genetic variation in Scandinavian brown trout (Salmo trutta L.): evidence of distinct sympatric populations. Hereditas, 83, 73-82.

ALLENDORF, F. W., STÅHL, G. AND RYMAN, N. 1984. Silencing of duplicate genes: A null allele polymorphism for lactate dehydrogenase in brown trout (Salmo trutta). Mol. Biol. Evol., 1, 238-248.

BALON, E. K. 1968. Notes to the origin and evolution of trouts and salmons with special reference to the Danubian trouts. Acta Societatis Zoologicae Bohemoslovacae, XXXII, $1-21$.

BERNATCHEZ, L., GUYOMARD, R. AND BONHOMME, F. 1992. DNA sequence variation of the mitochondrial control region among geographically and morphologically remote European brown trout Salmo trutta populations. Mol. Ecol., 1, 161-173.

BIANCO, P. G. 1990. Potential role of the palaeohistory of the Mediterranean and Paratethys basins on the early dispersal of Euro-Mediterranean freshwater fishes. Ichthyol. Explor. Freshwaters, 1, 167-184.

CHESSER, R. K. 1983. Genetic variability within and among populations of the black-tailed prairie dog. Evolution, 37, 320-331.

CRoss, T., WARD, R. AND ABreu-GroboIs, A. 1978. Duplicate loci and allelic variation for mitochondrial malic enzyme in the Atlantic Salmon Salmo salar L. Comp. Biochem. Physiol., 62, 403-406.

CROZIER, w. W. AND FERGUSON, A. 1986. Electrophoretic examination of the population structure of brown trout, Salmo trutta L., from the Lough Neagh catchment, Northern Ireland. J. Fish Biol., 28, 459-477.

ECONOMIDIS, P. S. AND BANARESCU, P. 1991. The distribution and origins of freshwater fishes in the Balkan peninsula, especially in Greece. Int. Rev. ges. Hydrobiol., 76, 257-283.

ELLiotT, J. M. 1989. Wild brown trout Salmo trutta: an important national and international resource. Freshwater Biol., 21, 1-5.

ESTOUP, A., PRESA, P., KRIEG, F., VAIMAN, D. AND GUYOMARD, R. 1993. (CT) $)_{n}$ and $(\mathrm{GT})_{\mathrm{n}}$ microsatellites: a new class of genetic markers for Salmo trutta L. (brown trout). Heredity, 71, 488-496.

FERGUSON, A. 1989. Genetic differences among brown trout, Salmo trutta, stocks and their importance for the conservation and management of the species. Freshwater Biol., 21, 35-46.

FERGUSON, A. AND FLEMMING, C. C. 1983. Evolutionary and taxonomic significance of protein variation in the brown trout (Salmo trutta L.) and other salmonid fishes. In: Oxford, G. S. and Rollinson, D. (eds) Protein Polymorphism: Adaptive and Taxonomic Significance, The Systematics Association, Special Volume No. 24, pp. 85-99. Academic Press, London.

FERGUSON, A. AND MASON, F. 1981. Allozyme evidence for reproductively isolated sympatric populations of brown trout Salmo trutta L. in Lough Melvin, Ireland. J. Fish Biol., 18, 629-642.

GARCIA-MARIN, J. L., JORDE, P. E., RYMAN, N., UTTER, F. AND PLA, C. 1991. Management implications of genetic differentiation between native and hatchery populations of brown trout (Salmo trutta) in Spain. Aquaculture, 95, 235-249.

GIUFFRA, E., BERNATCHEZ, L. AND GUYOMARD, R. 1994. Mitochondrial control region and protein coding genes sequence variation among phenotypic forms of brown trout Salmo trutta from Northern Italy. Mol. Ecol., 3, 161-172.

GUYOMARD, R. 1989. Diversité génétique de la truite commune. Bull. Fr. Pêche Piscic., 314, 118-135.

GUYOMARD, R. AND KRIEG, F. 1983. Electrophoretic variation in six populations of brown trout (Salmo trutta L.). 
Can. J. Genet. Cytol., 25, 403-413.

HAMILTON, E., FERGUSON, A., TAGGART, J., TOMASSON, T., WALKER, A. AND FAHY, E. 1989. Post-glacial colonization of brown trout Salmo trutta L.: Ldh-5 as a phylogeographic marker locus. J. Fish Biol., 35, 651-664.

HANSEN, M. M., LOESCHCKE, V., RASMUSSEN, G. AND SIMONSEN, V. 1993. Genetic differentiation among Danish brown trout (Salmo trutta) populations. Hereditas, 118, $177-185$.

HEDRICK, P. W. 1985. Genetics of Populations. Jones and Bartlett, Boston.

KARAKOUSIS, Y. AND TRIANTAPHYLLIDIS, C. 1988. Genetic relationship among three Greek brown trout (Salmo trutta L.) populations. Polskie Archiwum Hydrobiol., 35, 279-285.

KARAKOUSIS, Y. AND TRIANTAPHYLLIDIS, C. 1990. Genetic structure and differentiation among Greek brown trout (Salmo trutta L.) populations. Heredity, 64, 297-304.

KRIEG, F. AND GUYOMARD, R. 1983. Electrophoretic evidence for a large differentiation between brown trout populations of Corsica. C. r. Acad. Sci. Paris, 296, 1089-1093.

KRIEG, F. AND GUYOMARD, R. 1985. Population genetics of French brown trout (Salmo trutta L.): large geographical differentiation of wild populations and high similarity of domesticated stocks. Génét. Sél. Évol., 17, 225-242.

LEARY, R. F., ALLENDORF, F. W. AND KNUDSEN, K. L. 1993. Null alleles at two lactate dehydrogenase loci in rainbow trout are associated with decreased developmental stability. Genetica, 89, 3-13.

LI, w.-H. 1980. Rate of gene silencing at duplicate loci: a theoretical study and interpretation of data from tetraploid fishes. Genetics, 95, 237-258.

MACCRIMMON, H. R. AND MARShall, T. L. 1968. World distribution of brown trout, Salmo trutta. J. Fish. Res. Board Can., 25, 2527-2548.

NEI, M. 1972. Genetic distance between populations. Am. Nat., 106, 283-292.

NEI, M. 1975. Molecular Population Genetics and Evolution. Elsevier, New York.

NEI, M. 1978. Estimation of average heterozygosity and genetic distance from a small number of individuals. Genetics, 89, 583-590.
OsINOV, A. G. 1984. Zoogeographical origins of brown trout, Salmo trutta (Salmonidae): data from biochemical genetic markers. J. Ichthyol., 24, 10-23.

Osinov, A. G. 1989. Brown trout (Salmo trutta L., Salmonidae) in basins of the Black and Caspian Seas: A population genetic analysis. Genetika, 24, 1523-1534.

osinOV, A. G. 1990. The level of genetic variation and differentiation of the brown trout (Salmo trutta) in Tadjikistan. Biol. Sci. bull., 1, 37-41.

PRESA, P., KRIEG, F., ESTOUP, A. AND GUYOMARD, R. 1994. Diversité et gestion génétique de la truite commune: apport de l'étude du polymorphisme des locus protéiques et microsatellites. Génét. Sél. Évol., 26, 183s-202s.

RICE, w. R. 1989. Analyzing tables of statistical tests. Evolution, 43, 223-225.

ROHLF, J. 1990. NTSYS-pc. Numerical taxonomy and multivariate analysis system. Exeter Sofware, New York.

RYMAN, N., ALLENDORF, F. W. AND STÅHL, G. 1979. Reproductive isolation with little genetic divergence in sympatric populations of brown trout (Salmo trutta). Genetics, 92, 247-262.

STEINENGer, F. AND ROGL, F. 1984. Paleogeography and palispastic reconstruction of the Neogene of the Mediterranean and Paratethys. In: Dixon, J. E. and Robertson, A. (eds) The Geological Evolution of the Eastern Mediterranean, pp. 659-668. Blackwell Scientific Publications, Oxford.

SWOFFORD, D. L. AND SElANDER, R. B. 1981. BIOSYS-1. $A$ Computer Program for the Analysis of Allelic Variations in Genetics. Release 1. Department of Genetics and Development, University of Illinois at Urbana-Champaign, IL.

VAWTER, A. T., RoseblatT, R. AND GORMAN, G. C. 1980. Genetic divergence among fishes of the eastern Pacific and the Carribean: support for the molecular clock. Evolution, 34, 705-711.

VERSPOOR, E. AND JORDAN w. C. 1989. Genetic variation at the $M e-2$ locus in the Atlantic salmon within and between rivers: evidence for its selective maintenance. J. Fish Biol., 35, 205-213.

WEIR, B. S. AND COCKERHAM, C. c. 1984 . Estimating $F$-statistics for the analysis of population structure. Evolution, 38, 1358-1370. 